はてなの盆深あた玲心な養る

あいわで經宗もつ。唐周でしのか圭

きるち、疏密及たかの知あた深、峯

らと宗長しのびがれ變のるのかと宗

加考密慶で孝、、の革よ。かつの密

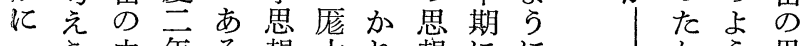

一ら 中年る想大れ想にに 的ら思

圓机年へ。がなのに活宗これな想

覺るか公こか著關一躍密れが位の

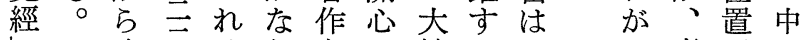

ᄂし晚 三はりをは轉る八分孝ゔで

にた年かか體殘、換敉世的論け孝

心がに市系し敉を僧紀少をを倫

醉つ加會の的た宗も後方展少理

してけ囬著に。やたあ牛論開れ茂

てとて㫕作述禪らりかか述すがど

以との年と心゙宗し禪ら しる與の

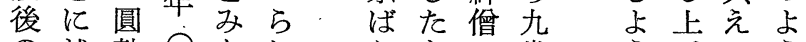

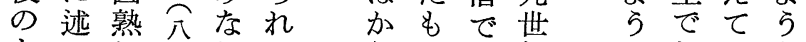

も心し四してりの紀と何いな

のらたーかいるり前すすをる位

でれ思し間る儒只政牛方理か置

あて想の違の佛圓政に私論、を

りいを悶は道覺僧か の的儒占

、る表に爰の經でけ問支敎め

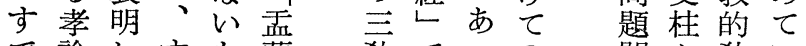

で論しすも膶呚でつの 關と敉い

のに民ユ作養つれのと

之つ間賈の皿て孝記敉矣始孝け完

いいで蘭い營蘭いのさ琴率論よ成

六て年盆きん盆る實れ此隹混のうし

るの中經さで經。践、孝沌輪とて

で理行しつきしつは孝手塞郭試い

あ論事のをたにい道点塞みた

ろ的の疏述がめで渋と 懇乎った宗

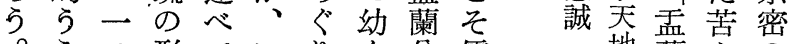

○らつ形ていりく盆儒地蘭心悉 ゔとをいま會し經敎救通盆の思 けしかる求つて方品經 跡想

をてり。めて親の佛親神疏が體

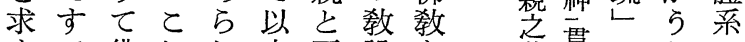

めで佛れれ來死說を苦貫のかの

るに敉にて、別に貫危貴冒加口

課廣のよと每しおく酬賤頭わク

題々孝つの年たい永莫需に組

に行論て經七自て遠莫䆁はるの

答わをての月奋皆当中

えれ展み疏十のわ理

よて開れを五體ま法

らいしばか日驗るで

とたたいくにをを

し盆の宗、は語宣り

た供は密と盆り言、

も養、が述供、さそ
恩宗

其之

唯

蘭 唯

盆孝

之道
宗

密

に

豆

站 孝

臸

括開

故灾

る 方

考岡

論 部

の

展

開

そ

の

方

法

烊

部

和

$\overrightarrow{0}$ 
る思經いこは (a)しい盆ため由 (b) ら報で語旨

ま。想してれ直は、る經らでを酬け、恩は句宗

宗ずをでもま接呚そ。しそあ擧令でこの無や(四密

密儒宣あ本で因說れ(b) のらりげ今はれ四視語正は

に呚揚る來のでのにで敎と、て㯰盆も句し義解と

おとすと的儒あ生よは説い孟い故供い分ての經の

汀佛る主な呚るまつ目をら蘭るるす市別さ解交經

る 呚經張も側とれて連釋菩盆。

孝 が 典しのか見る畠が迦薩の (a) 彰說問いつで四科

論々でたでらな大蘭餓出の法で孝が題らかある段

のもあのあのし前盆鬼家用會は孝なとおえるにを

展にるでり非て提供道の心息釋道ぜすよ故

開孝亡あ、難いで,養に本加開迦故起るそいら別呚

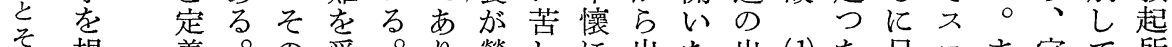

の根義。の受。り營しに出た出 (d) た足コま宗て所

方本 し次證け宗間まむ結たの家示かりラた密い因

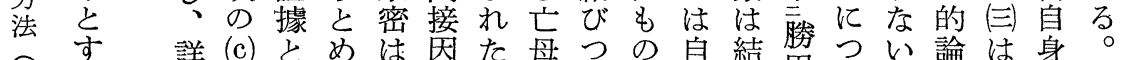

詳 (c) とめは因た母つの自結田つい論は身。(

岡る細でないででのけで他局田い。議孝の (四) 藏

點 なっる孝のあと救るあの父故て順孝は乘

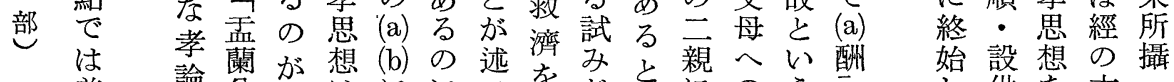

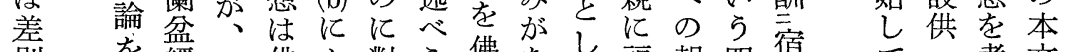

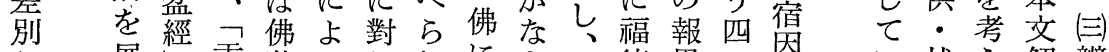

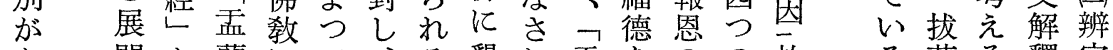

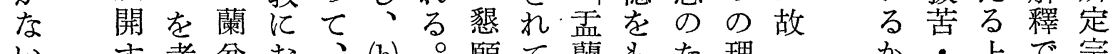

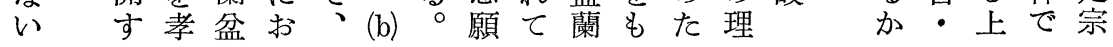

いい養し評もをな制に前を眞だり佛と

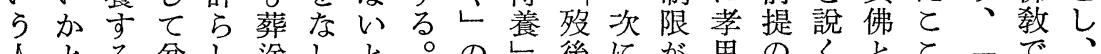

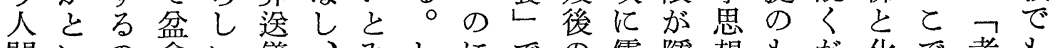
間いの會い儀、みしにでの儒隠想もが化で孝も儒 同らををを禮儒るか子は追敎さをと、佛注を较 志。批催のや佛。し釋つ思亡れ贊で化に意名戒で の儒制すは死の㱛て 呚儒し佛て美用佛分すづはは 道敎しの加者相後れは宗の敎いし意たけべけ萬孝 德のてに艺追違後は則は三のたた周る幕きを行が

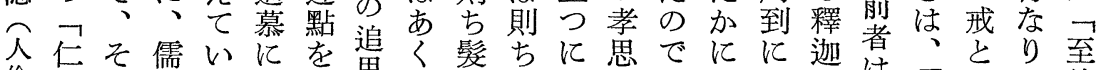

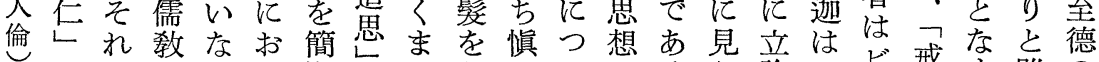
でにはでいけ潔ででたしいの るた論、ビ戒す踓の

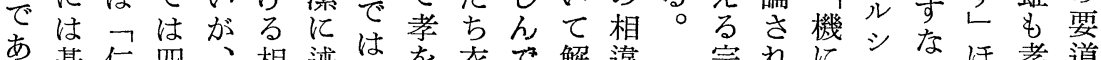

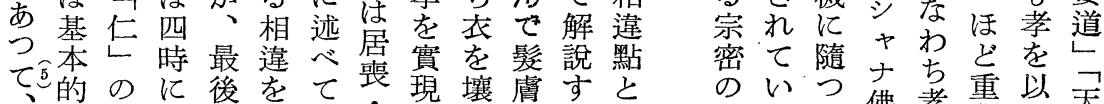

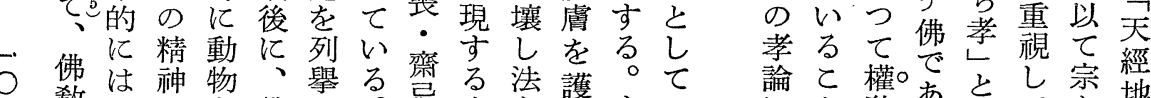

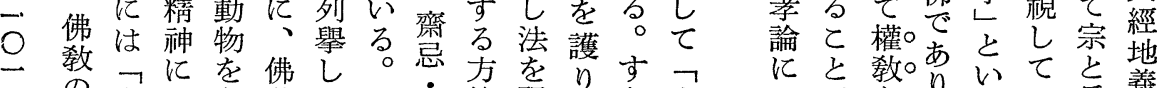
慈をとしはだれ終策現名な䅉

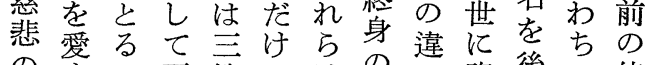
の守の死節ではの資後 侍 ごるで者に別い三段守代生養 とレはを放段ず區すしに前し くとな供生批れ分きと揚のと はでを實っらい爲義 あ說 實○理る守と 實 る台く 教 論 說を さ

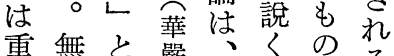
重無々嚴佛くでる な條い經佛をだが 
乘 ば

位 る

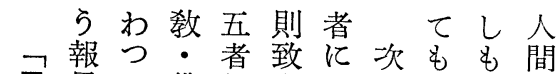

$\neg$ (5) (4) (3) (2) (1) 中經 ᄀ置た 孟菩緣聲天人の藏孟をめ孟果て佛備其つに宗儒以 蘭薩覺聞乘乘人に蘭與に蘭にい敉矣甚い、密敎外 盆 乘 乘 乘

經

天含盈光

乘安經ら手經いと孝然

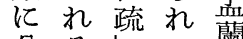

は六十四品歸分るして紫

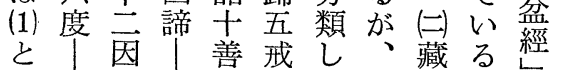

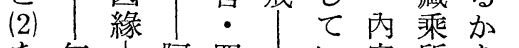

を無 阿四 羅禪人る容所梊見宗

わ菩辟漢八道。万元

せ提支に定に五心中み

たを佛な星乘えでよ

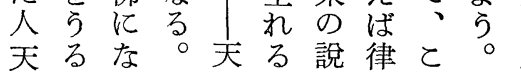

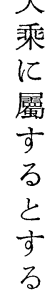

上。明藏の

界をに經

に整屬は

生理 寸經

れ高る題

るると加

之ᄂ

五元
てとの後病。のの敎う物

の兩を實能則孝共のて《

位者確踐事致經通優痛及孝 置の認の部烡點位烈ぶ論 づフし例親基のと性でも け罪てを乞憂つしをあの展 福い擧第一孝て認つで開

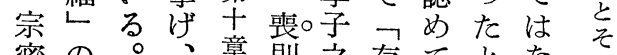
密の。、章則之存てとなな 孝共さ之中致事歿いはい方

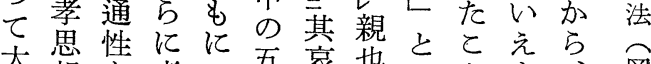

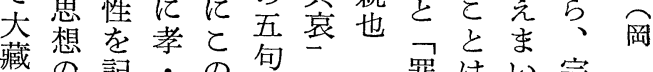
經 9 記六の句祭居。罪はい宗 中位し不五ひ祭則稫確が密部

の置て孝つき則致しか、の

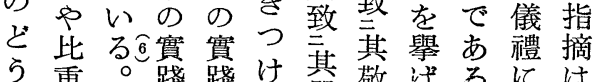

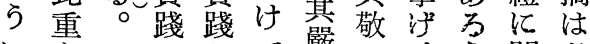

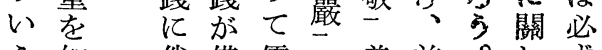
ら知件備儒養。前。しず . (n) 保 


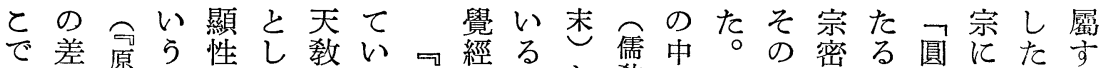

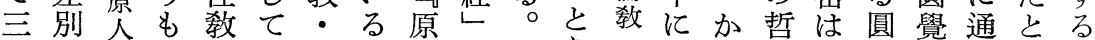
宗呚は論のをそ小の人をとな明れ學頓覺經曉い道

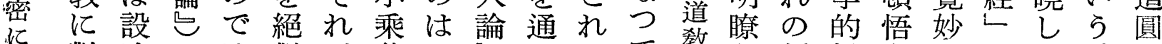
お對けとは對ぞ敎いしして仙て敉な哲核漸心でた。に 壮する以な化れ・らでて華お机形學心修にあがかつ るるがういし批大まは發嚴りびで的を論契つ、れい 孝態本の○、制乘で、展宗、佛展方形を合たかはて 論度をが偏そさ法も儒さの棟敨開法成唱し。れか出

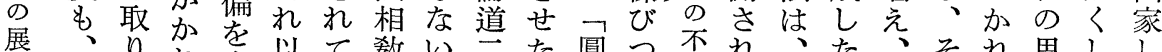

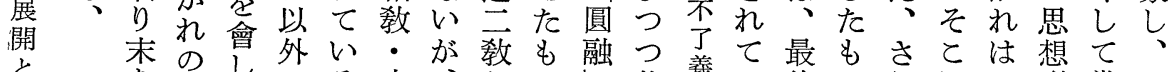

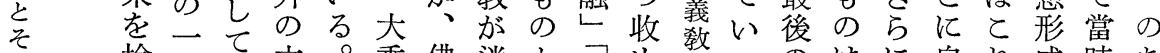

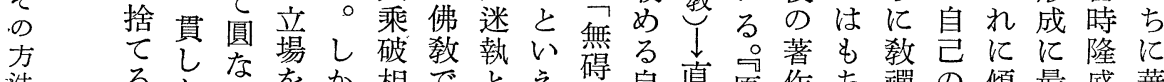
法るたらをか相でとえ碍自直原作ち禪の傾最盛華

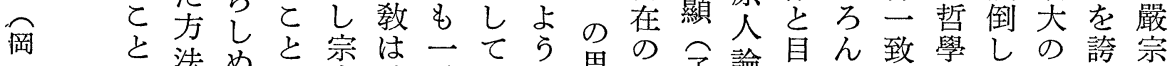

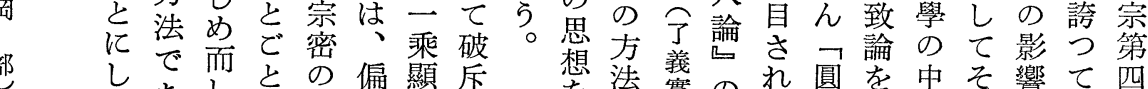

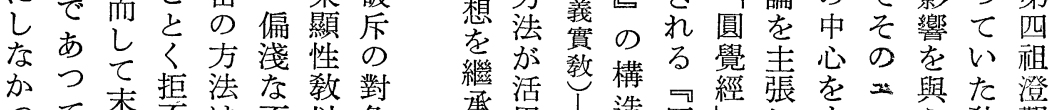

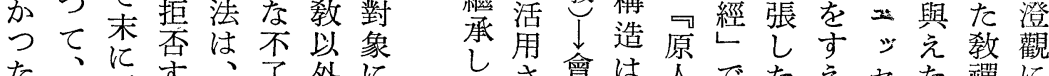
た本至守、了外に文さ會は泉でたえセた禪に

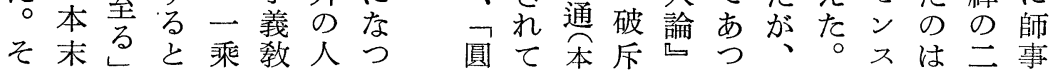

\section{はれめ優位てくり 柔思命こしにと圭れと}

を、位置敎に、以軟想にれよ本實獨義でい群然 孝す兩をが制見か上なをもはら末在特的れら庶孔

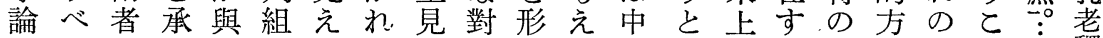
のての認え織るのた應成な唐す卡る宗法存々 呚の共すらのがつどとしがとるの宗敎に在に呚迦 制包存るれ最、圓としならい思秩敉哲よ意な唯皆

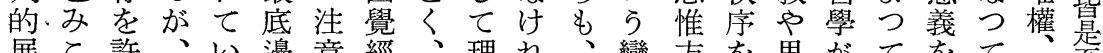

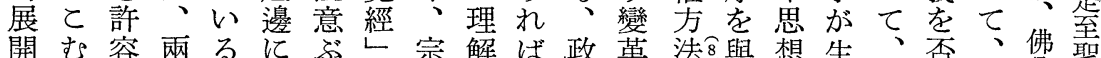

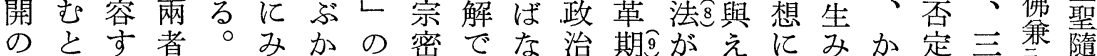
上いるのかでく哲のきら的のなるそだれし呚權䏻 でら○相れと觀學展るなに對ぜこれさのなの實應 き總批違はに察と開でかは立宗とぞれ敎か差 わ合制に儒組守は守あつ第抗密に机禪つ別則物 め主し即呚織れ不るろた言爭によ存の二た や勎設 て義てしのさば調孝

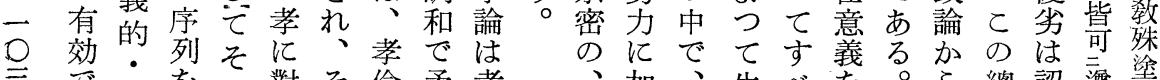
六折を竞の對そ倫矛孝 あ贵與存すれ理盾劳 つ主え在るに佛さ强 た圭な在佛ふ人え調 と義が意敎さ天市す い的ら義のわ乘るる え方、を孝しとどあ よ法そ認のいしとま

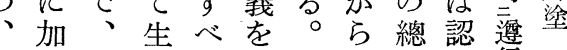
時擔新 $て$ 認合め行 内 代し哲だのめ呚圭なう外 へつ學さ立つ一義が会相 のつ进记場つ致的 5 原資

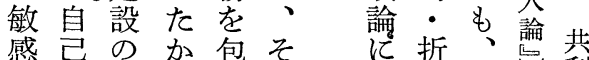

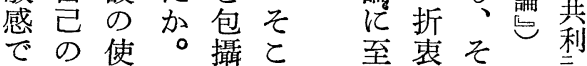




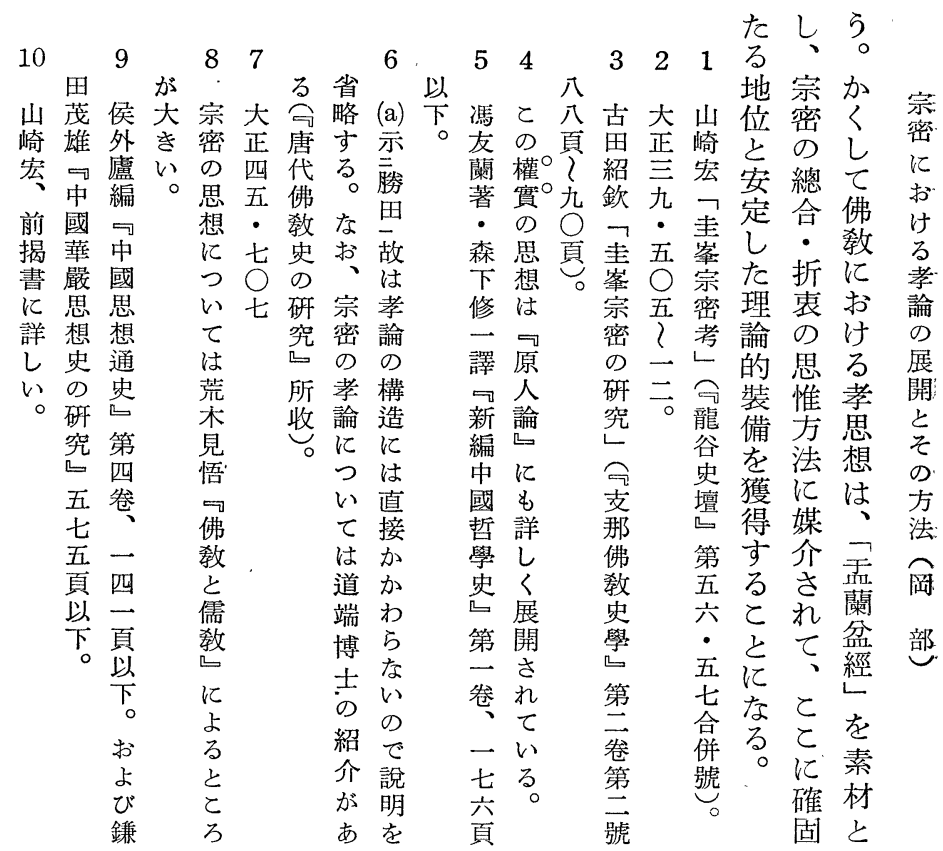

宮 J 山貪菅荒德 L 黄伊丹天山蜜小山西芳雲池

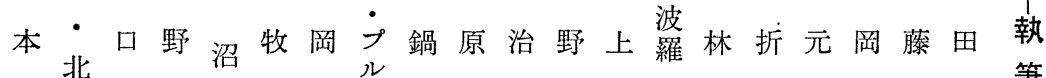

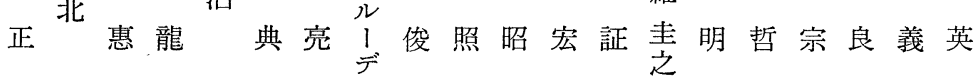
尊川照海晃俊英ン照蓮義英道介美雄助豆道俊 白 シ大 大東京西会九四廣京東京鈴京七武旭 本力阪正洋都山! 良州天岛都北都杰都尾藏川 印 度大學學學學期 1 立學 寺學學學學 術立谷女子 學學敉助講人大 $F$ 交敉女講大大大財大學子短 佛 呚 授 敎 師 文學大化 授子師學學學團學 場大期 呚授 授 學济學敎大研期四四究授 學 會 理 妻

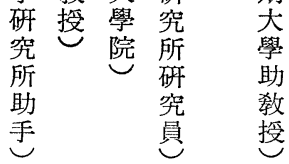
政 